\title{
An Empirical Economic Assessment of the Costs and Benefits of Bank Capital in the United States
}

\author{
Simon Firestone, Amy Lorenc, and Ben Ranish
}

\begin{abstract}
We evaluate the economic costs and benefits of bank capital in the United States. The analysis is similar to that found in previous studies, though we tailor it to the specific features and experience of the U.S. financial system. We also make adjustments to account for the impact of liquidity- and resolution-related regulations on the probability of a financial crisis. We find that the level of capital that maximizes the difference between total benefits and total costs ranges from just over 13 percent to 26 percent. This range reflects a high degree of uncertainty and latitude in specifying important study parameters that have a significant influence on the resulting optimal capital level, such as the output costs of a financial crisis or the effect of increased bank capital on economic output. Finally, the article discusses a range of considerations and factors that are not included in the cost-benefit framework that could have a substantial impact on estimated optimal capital levels. (JEL G18, G21, G28)
\end{abstract}

Federal Reserve Bank of St. Louis Review, Third Quarter 2019, 101(3), pp. 203-30.

https://doi.org/10.20955/r.101.203-30

\section{INTRODUCTION}

We perform an economic analysis of the long-term costs and benefits of different levels of system-wide bank capital and estimate optimal Tier 1 capital levels under a range of modeling assumptions. $\frac{1}{}$ Within our framework, the benefit of bank capital is to reduce the probability of costly future financial crises. The marginal benefit of bank capital generally decreases as capital levels rise; the potential improvement from reducing the frequency of crises becomes more limited as the frequency of crises approaches zero. The aggregate economic costs of bank capital stem from an increase in banks' cost of capital. This increase is passed on to borrowers in the form of higher credit costs and lowers gross domestic product (GDP). In our framework, the marginal cost of bank capital is constant.

The shaded region in Figure 1 shows a range for our estimated marginal net benefits of capital. At levels of capital up to about 13 percent, the shaded region lies above the horizontal

Simon Firestone is a principal economist, Amy Lorenc was a senior financial institution policy analyst, and Ben Ranish is a senior economist at the Board of Governors of the Federal Reserve System.

( ) 2019, Federal Reserve Bank of St. Louis. The views expressed in this article are those of the author(s) and do not necessarily reflect the views of the Federal Reserve System, the Board of Governors, or the regional Federal Reserve Banks. Articles may be reprinted, reproduced, published, distributed, displayed, and transmitted in their entirety if copyright notice, author name(s), and full citation are included. Abstracts, synopses, and other derivative works may be made only with prior written permission of the Federal Reserve Bank of St. Louis. 


\section{Figure 1}

\section{Estimates of the Net Benefits of Additional Tier 1 Capital (Marginal Net Benefits of Capital)}

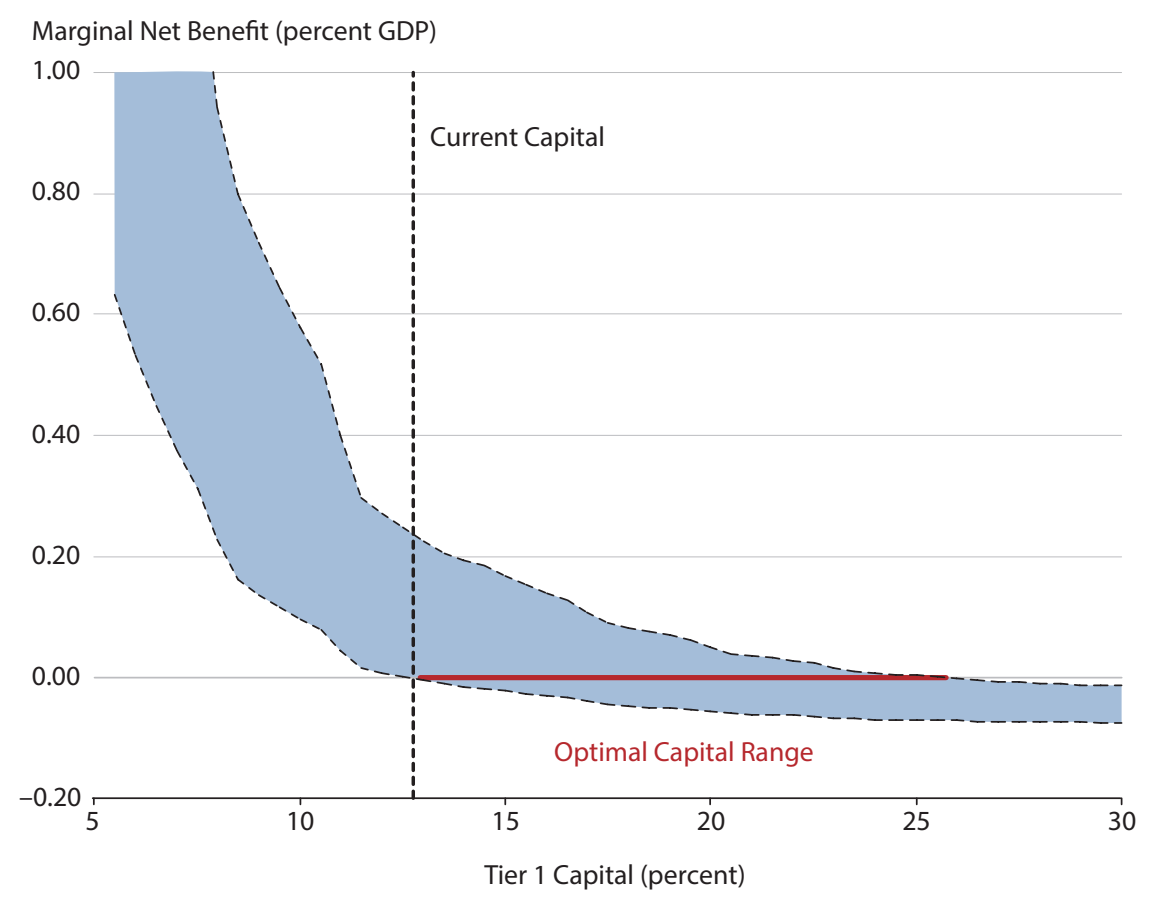

axis. This implies that our estimated range for the benefits of additional capital remains positive until Tier 1 capital ratios reach 13 percent. For levels of capital between 13 percent and 26 percent, the shaded region overlaps the horizontal axis. This overlap implies that our estimated benefits of additional capital for this range may be positive or negative, depending on the modeling assumptions used.

The width of the shaded region in the plot represents uncertainty around our estimates of the costs and benefits associated with the level of bank capital. The upper bound of this region represents our low estimate of the costs and high estimate of the benefits of bank capital. Specifically, it assumes that the effects of financial crises are permanent and that banks pass only 50 percent of capital-related cost increases on to borrowers. The lower bound of this region represents our high estimate of the costs and low estimate of the benefits of bank capital. Specifically, it assumes that the effects of crises diminish gradually over time and that banks pass all capital-related cost increases on to borrowers. 2 We note that this plot shows levels of actual capital rather than minimum required capital. Because banks generally hold a buffer above and beyond the minimum required capital, we expect that optimal minimum capital requirements may be a bit below the range shown in Figure 1.

There is an extensive literature on financial crises in advanced economies and the relationship between bank capital and macroeconomic risk. Our methodology builds on studies by the Basel Committee on Banking Supervision (BCBS) (2010), Brooke et al. (2015), and the 
Federal Reserve Bank of Minneapolis (2016). All studies use the same basic framework; the effects of increased bank capital on the probability and severity of a crisis are compared with the increase in the cost of credit and associated reduction in GDP level. The BCBS (2010) study uses a meta-analysis of the academic literature, combined with results from various countryspecific supervisory models, to quantify these effects. Brooke et al. (2015) and the Minneapolis Fed (2016) use both the existing literature and substantial original data analysis for calibration to the U.K. and U.S. economies.

Our approach differs from these studies in some significant ways. For example, we use adjustments and controls to account for the effects of new liquidity requirements and resolution requirements for failing firms. We also use Romer and Romer's (2015) generalized least squares (GLS) estimates of the severity of financial crises to reduce the result's dependence on data from inherently more volatile and smaller economies that are arguably less relevant to the United States. $\underline{3}$ We provide estimates of the severity of financial crises that assume permanent effects of financial crises on GDP, as well as alternative estimates that assume persistent but decaying effects. Finally, unlike the BCBS (2010) and Brooke et al. (2015) studies, we design the research to ensure, where possible, that the analysis is tailored to the specific features of the U.S. financial system so that the results are relevant for considering capital regulatory policy in the United States. Our results imply larger optimal capital levels than those in Brooke et al. (2015) and similar levels to those in the BCBS (2010) and Minneapolis Fed (2016) studies. Like past studies, our framework addresses broad changes in capital rather than targeted requirements that apply to specific banks, such as the global systemically important banks (GSIBs) surcharge and the Comprehensive Capital Analysis and Review (CCAR). Our framework assumes that all banks choose the same capital ratios, and we do not account for the heterogeneity of the U.S. capital framework resulting from targeted regulations.

\section{INSTITUTIONAL ENVIRONMENT}

Two new U.S. enhancements to large-bank safety and soundness affect the relationship between bank capital levels and the macroeconomy: increased resolvability of failing firms and liquidity requirements. In our analysis, we consider the effects of capital in the presence of both.

A number of resolution-planning requirements have been adopted to ensure rapid and orderly resolution in the event of financial distress or failure of a company. Of particular importance are the long-term debt and the total loss-absorbing capacity (TLAC) requirements. These requirements are designed to create a source of funds for recapitalization. 4 They apply to top-tier U.S. bank holding companies that have been designated as GSIBs and to U.S. intermediate holding companies of foreign GSIBs. These institutions must maintain a certain amount of eligible long-term unsecured debt that can be converted to equity for the purpose of absorbing losses or recapitalization in the event of failure. Requirements became effective January 1, 2019.

In addition to complying with the long-term debt and TLAC requirements, large U.S. bank holding companies must submit annual orderly resolution plans, commonly known as 


\section{Firestone, Lorenc, Ranish}

living wills, to the Federal Reserve System. These plans should facilitate the rapid and orderly resolution of a firm in the event of failure and prevent contagion among broader financial markets. Beyond resolution-planning requirements, the orderly liquidation authority provided to the Federal Deposit Insurance Corporation (FDIC) by Title II of the Dodd-Frank Wall Street Reform and Consumer Protection Act of 2010 increases the resolvability of financial firms. The orderly liquidation authority provides an alternative to standard bankruptcy that allows the FDIC to carry out the liquidation of a failing financial company, aiming to minimize systemic risk and moral hazard.

Shocks to the value of financial system assets are amplified by liquidity shortfalls. Banks with short-term funding requirements exceeding their liquid assets may find themselves vulnerable to "fire sales" of illiquid assets when such shocks occur. Through their price impact, fire sales can trigger the loss of funding liquidity and asset sales at other banks, potentially threatening the solvency of the entire system. $\frac{5}{}$ Consequently, liquidity requirements are also likely to reduce the probability of a financial crisis. We include adjustments for the effect of liquidity regulations in our estimated financial crisis probabilities.

The liquidity coverage ratio (LCR) ${ }^{6}$ was adopted in the United States in 2014, with all phase-in completed by January 2017. It applies in full to all U.S. institutions with at least $\$ 250$ billion in total assets or at least $\$ 10$ billion in on-balance sheet foreign assets. Less-stringent requirements apply to institutions with between $\$ 50$ billion and $\$ 250$ billion in total assets and less than $\$ 10$ billion in on-balance sheet foreign assets. The LCR requires banks to maintain an amount of high-quality liquid assets sufficient to cover expected net cash outflows during a 30-day stress period. This amount is a weighted sum of specific high-quality liquid assets, with higher weights on the most-liquid assets. Expected net cash outflows are fixed by regulation and based on the type of liabilities. Shorter-term and more-runnable liabilities are associated with the highest outflow rates.

Both resolution and liquidity reforms are likely to reduce the expected frequency and costs of future financial crises, and thus reduce the marginal benefits of bank capital. As these reforms are new, their effect is subject to considerable uncertainty. In addition, the regulatory landscape continues to evolve as regulators consider ways to simplify and tailor post-crisis reforms. Future changes to resolution and liquidity reforms could require a reassessment of their potential impact on future financial crises. With that said, we discuss how we incorporate the current expected effects of these enhancements to large-bank safety and soundness within our framework in the next section.

\section{THE ECONOMIC BENEFITS OF BANK CAPITAL}

To measure the benefits of bank capital, we first estimate bank capital's role in reducing the probability of a financial crisis (Section 3.1) and then multiply this by the costs of financial crises (Section 3.2). We rely on definitions of "financial crisis" developed in previous surveys, as defining crisis is a non-trivial exercise. When estimating the probability of a financial crisis, we rely on criteria and crises identified by Laeven and Valencia (2012). When estimating the costs of financial crises, we use results from Romer and Romer (2015), who developed a con- 
tinuous narrative-based measure of financial distress. $\underline{Z}$ We discuss additional, potentially significant, benefits of bank capital not captured in this framework (Section 6).

\subsection{Probability of a Financial Crisis}

As with past studies, we estimate the probability of a financial crisis starting via the following two approaches with distinct strengths and weaknesses: a "bottom-up" bank-level simulation and a "top-down" country-level regression. In our reported results, we use the

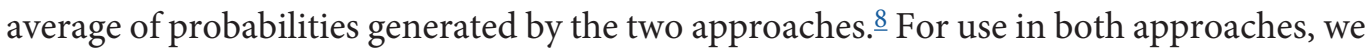
collect data spanning 24 developed countries from the Organisation for Economic Co-operation and Development (OECD) for 1988-2014. ${ }^{-}$The two sections that follow describe each of these approaches and the results they deliver in greater detail.

Bottom-Up Approach. In this approach, we simulate net income for U.S. banks and then determine whether the aggregate capital shortfall that results is large enough to classify as a financial crisis, using the definition of financial crisis described in previous surveys. In the process, we adjust the simulated income to account for large U.S. banks now being subject to liquidity requirements as well. This adjustment is discussed in more detail below. To implement this approach, we use bank-level data on total assets, risk-weighted assets (RWA), net income, Tier 1 capital, and asset liquidity ratios from Bankscope. These data have good coverage for 1988-2014. .10 We use these historical data to simulate net income for U.S. banks. For each simulation, we first randomly pick a single country-year scenario; for example, "France 2008." Then, for each of the 5,935 U.S. banks at the end of 2015, we randomly draw (with replacement) a value for two-year net income/RWA from within the set of large banks present in that country-year scenario. $\frac{11,12}{}$ We use two-year net income to roughly match the length of CCAR stress periods. This captures the fact that bank losses are predictable over multiple years in stress periods, possibly because of the smoothing of asset value shocks on balance sheets. $\underline{13}$

Next, we compute the aggregate capital shortfall that results from the simulated net income draws and a range of initial Tier 1 capital levels. We follow Brooke et al.'s (2015) approach by identifying crises as simulations where the aggregate shortfall exceeds 3 percent of GDP ( $\$ 540$ billion), the level Laeven and Valencia (2012) define as a significant recapitalization. This shortfall is measured relative to a threshold of 8.24 percent. This threshold is chosen so that the average probability of a crisis generated by the model when applied to the United States (1989-2014) equals the average probability of a crisis in an advanced economy (4.0 percent per Laeven and Valencia, 2012). $\underline{14}$ With our shortfall threshold and crisis definition, if all U.S. banks had the same Tier 1 capital ratios, a crisis occurs whenever this ratio falls below about 4.7 percent. We run our simulation 10,000 times, each time using a random set of net income draws from a randomly selected country-year scenario as described above.

For most of the historical data period, major liquidity regulations were not in effect. If they were, banks may have had more liquid assets to sell off during stress periods, reducing the extent of loss-magnifying fire sales. To account for the effect of liquidity regulations on loss magnitudes, we first estimate the relationship between asset liquidity and loss magnitudes. We use this to adjust the draws of negative bank income upward by an approximation of how 


\section{Table 1}

\section{Results of the Bottom-Up Approach: Estimated Probability of a Financial Crisis}

\begin{tabular}{|c|c|c|c|}
\hline $\begin{array}{c}\text { Tier } 1 \text { capital } \\
\text { ratio }(\%)\end{array}$ & $\begin{array}{c}\text { No adjustment for liquidity } \\
\text { regulations or increased } \\
\text { resolvability } \\
{[1]}\end{array}$ & $\begin{array}{c}\text { Adjustment for liquidity } \\
\text { regulations, but not } \\
\text { increased resolvability } \\
{[2]}\end{array}$ & $\begin{array}{l}\text { Adjustment for liquidity } \\
\text { regulations, and } 30 \% \\
\text { reduction for increased } \\
\text { resolvability } \\
{[3]}\end{array}$ \\
\hline 8.0 & 3.8 & 3.2 & 2.6 \\
\hline 11.0 & 1.9 & 1.8 & 1.3 \\
\hline 14.0 & 1.4 & 1.4 & 1.0 \\
\hline 17.0 & 1.0 & 1.0 & 0.7 \\
\hline 21.0 & 0.8 & 0.7 & 0.5 \\
\hline 25.0 & 0.7 & 0.7 & 0.5 \\
\hline
\end{tabular}

much higher income would have been if the draw had been from an LCR-compliant bank. This higher income translates into a lower aggregate net shortfall, and thus a lower probability of a financial crisis. Further details of this adjustment are available in the appendix.

Finally, other impact studies have suggested that loss-absorption requirements, such as TLAC, may reduce the probability of a financial crisis. In theory, greater reliance on debt that is priced to reflect risk may restrain bank risk-taking. TLAC may reduce the risk of individual or even systematic bank failures. Based on this argument, the Financial Stability Board (2015) relies on work by Afonso, Santos, and Traina (2014) and Marques, Correa, and Sapriza (2013) to estimate that TLAC reduces the probability of a financial crisis by 30 percent. $\frac{15}{}$

Table 1 shows our bottom-up estimates of the probability of a financial crisis across a wide range of Tier 1 capital levels. Column [1] presents our estimates without the liquidity requirement-based adjustment to loss magnitudes described above. Column [2] includes this adjustment, showing that it reduces the estimated probability of a financial crisis by about 3 to 14 percent, depending on the level of capital. Column [3] presents a 30 percent reduction applied to all probabilities to account for increased resolvability of failing firms. Given the multiple uncertainties in this approach, we treat the magnitude of this adjustment with caution.

The probability of a financial crisis declines sharply as capital levels rise. However, the rate of this change in probability, in absolute and relative terms, is more gradual as the level of capital rises. This observation is due to the fat-tailed historical distribution of stress losses, upon which all empirical bottom-up approaches rely. Once the relatively common milder stress periods are avoided (at Tier 1 ratios around 15 percent), there are relatively few crises remaining that can be avoided without substantially greater amounts of capital. Liquidity requirements have a modest effect on the probability of a crisis, with the exception of cases when capital is very low.

Top-Down Approach. In our top-down approach, we use a cross-country logit model to predict the probability of a financial crisis starting given the financial system's capital and 
asset liquidity, and control for other sources of economic fragility. Our annual data covers the same set of countries and years as used in our bottom-up approach, although we omit country-years where there is an ongoing crisis. $\frac{16}{}$ We adopt the definition and dates of systemic banking crises developed in Laeven and Valencia (2012). This definition requires the following two conditions be met:

(i) significant signs of financial distress in the banking system (as indicated by significant bank runs, losses in the banking system, and/or bank liquidations); and

(ii) significant banking policy intervention measures in response to significant losses in the banking system.

This definition is more flexible than the capital shortfall-based definition of a crisis used in the bottom-up approach, allowing for a more nuanced definition of what constitutes a crisis.

We derive country-level Tier 1 capital and asset liquidity ratios for each year using the bank-level data from Bankscope described previously. We collect implied volatility from the Chicago Board Options Exchange's Volatility Index ${ }^{\oplus}$ VIX $\left.^{\oplus}\right)$ and the ratio of total privatesector credit to GDP from the World Bank. $\frac{17}{1}$ To further control for fragility related to trade imbalances and asset valuation, we also collect data on the current account balance (as a percent of GDP) from the World Bank and the price-to-income ratio from the OECD. Note that $\mathrm{VIX}^{\oplus}$ is the only explanatory variable in our model that is not country specific.

We run two separate logit regressions. These regressions are indicated by the two specifications below, where the function $f$ is the logistic function, and $c$ and $t$ denote country and year, respectively. Specification (1) uses only VIX ${ }^{\circledR}$ and credit to GDP as macroeconomic controls. Specification (2) adds current account balance and home price-to-income ratios. We opt to use two specifications because the additional control variables in specification (2) are missing for around one-third of our observations. The first specification thus uses a larger sample, while the second specification uses a more complete set of variables.

$$
\begin{aligned}
& \text { Probability }\left(\text { Crisis }_{c t}\right)=f\left(\text { Tier1_Capital }{ }_{c, t-1},{\text { LiquidAsset } \%_{c, t-1}, \text { VIX }}_{t-1}, \text { Credit_GDP }_{c, t-1}\right)
\end{aligned}
$$

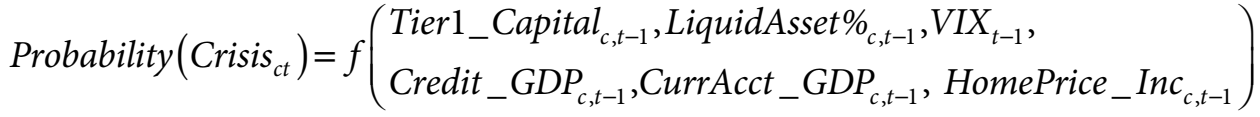

Results of both specifications are shown in Table 2. Specification (1) is a more appropriate fit for the data based on log likelihoods and the Akaike Information Criterion, but it is important to note that the differences in fit and common coefficients between the specifications are largely driven by the completeness of the data in the samples rather than the covariates chosen. The VIX ${ }^{\circledR}$ is highly statistically significant in both specifications. Liquid asset share is not statistically significant in either specification, which will impact how we consider the effect of liquidity regulations, as discussed shortly.

We first use estimates from these two regressions to predict the probability of a crisis under counterfactual levels of Tier 1 capital without any adjustments for regulations put in 


\section{Table 2}

\section{Regression Results of Both Specifications of the Top-Down Approach}

\begin{tabular}{|c|c|c|}
\hline & & \\
\hline & Proba & al crisis \\
\hline & Specification (1) & Specification (2) \\
\hline Tier 1 ratio & $-7.251(10.089)$ & $-24.733^{*}(15.691)$ \\
\hline Liquid asset share & $1.744(1.768)$ & $4.034(2.603)$ \\
\hline Credit to GDP ratio & $1.243^{* * *}(0.454)$ & $0.733(0.702)$ \\
\hline VIX ${ }^{\circledast}$ & $0.090^{* * *}(0.031)$ & $0.095^{* * *}(0.035)$ \\
\hline Current account balance & & $-3.388(5.231)$ \\
\hline Price-to-income ratio & & $2.707^{* *}(1.134)$ \\
\hline Constant & $-5.879 * * *(1.230)$ & $-6.893^{* * *}(1.797)$ \\
\hline Observations & 434 & 328 \\
\hline Log likelihood & -82.144 & -66.512 \\
\hline Akaike Information Criterion & 174.288 & 147.024 \\
\hline
\end{tabular}

\section{Table 3}

Results of the Top-Down Approach

\begin{tabular}{cccccc} 
& \multicolumn{4}{c}{ Annual probability of a financial crisis (\%) } \\
\cline { 2 - 3 } Tier 1 ratio & \multicolumn{2}{c}{ So adjustment } & & \multicolumn{2}{c}{ Adjustment for increased resolvability } \\
\cline { 2 - 3 } \cline { 5 - 6 } & Specification (1) & Specification (2) & & Specification (1) & Specification (2) \\
\hline 8.0 & 6.3 & 6.8 & 4.4 & 4.7 \\
\hline 11.0 & 5.2 & 3.3 & 3.6 & 2.3 \\
\hline 14.0 & 4.3 & 1.5 & 3.0 & 1.1 \\
\hline 17.0 & 3.5 & 0.7 & 2.5 & 0.5 \\
\hline 21.0 & 2.7 & 0.2 & 1.9 & 0.2 \\
\hline 25.0 & 2.0 & 0.1 & 1.4 & 0.1 \\
\hline
\end{tabular}

place after the 2007-09 Financial Crisis. For each Tier 1 capital level, we take the average of probabilities across all country-years as our estimate of the average probability of a crisis over the business cycle (i.e., over the distribution of non-crisis macroeconomic states) for that capital level. These baseline results are in columns 2 and 3 of Table 3 . These results may overestimate the probability of a crisis because recent regulations have greatly increased the resiliency of the U.S. financial system and are not reflected in the data used to estimate the regressions. 
To account for this overestimation of the probability of a financial crisis, we consider the effects of compliance with new liquidity regulations and the increased resolvability of failing financial firms. Liquidity regulations, particularly the LCR requirement, would be best captured by our share-of-liquid-asset variable. As shown in Table 2, the estimated coefficient for this variable is positive but insignificant in both specifications of our model. For this reason, accounting for liquidity regulation compliance would not significantly alter the results of the top-down approach, and we do not perform an adjustment for liquidity regulation.

We next consider the effect of increased resolvability of failing financial firms. We follow the adjustment method of the bottom-up approach and assume a 30 percent reduction in the probability of a crisis as a result of the increased resolvability of firms. $\frac{18}{}$ Results reflecting this reduction are shown in the final two columns of Table 3. These results are most representative of the probability of a crisis in the current regulatory environment.

The differences between the two specifications show that the relatively limited number of financial crises mean that results can be sensitive to the sample selection and choice of macroeconomic control variables. As in the bottom-up approach, both specifications of the model attribute higher Tier 1 capital ratios to lower probabilities of crises. However, specification (2) shows far greater sensitivity of probabilities to capital ratios and produces estimates closer to those of the bottom-up approach. In this case, most of this difference is driven by differences between the data sample used in the two specifications. $\frac{19}{}$

\subsection{Costs of Financial Crises}

There are several reasons why financial crises reduce economic growth. A negative shock to lending reduces demand for output, leading to less investment in capital and research. The increased uncertainty of an economy in crisis can further reduce investment. We quantify the size of this effect in this section.

There are three steps to measuring the effects of a financial crisis on GDP: deciding if a crisis's effects are permanent, measuring the time-varying effects of the crisis throughout its duration, and calculating the present value of the sum of these effects over time. If there are no permanent effects, the cost is simply the present value of the short- and medium-term effects. We discuss each of these steps below.

Does a Crisis Have Permanent or Persistent Effects? Some past studies have assumed that crises have only temporary effects, while others assume a permanent decrease in output. The duration of the effects is especially important because it can change the cost estimate by an order of magnitude. To illustrate the difference between the two approaches that measure the cost of a crisis, consider Figure 2. The dashed line represents growth without a crisis, while the solid line represents the baseline until a financial crisis reduces growth for two years. The blue bars are annual GDP growth rates. Exiting the crisis leads to one year of above-trend growth, followed by a return to trend growth. The transitory costs of a crisis would be given by the area of the difference between the solid and dashed lines for the first two years of the crisis, adjusted for discounting. ${ }^{20}$ Measuring the permanent effects would include the area of the discounted difference between the two lines from the start of the crisis. Of course, if 
Figure 2

\section{GDP Level (left axis) and Growth (right axis), Hypothetical Economy}

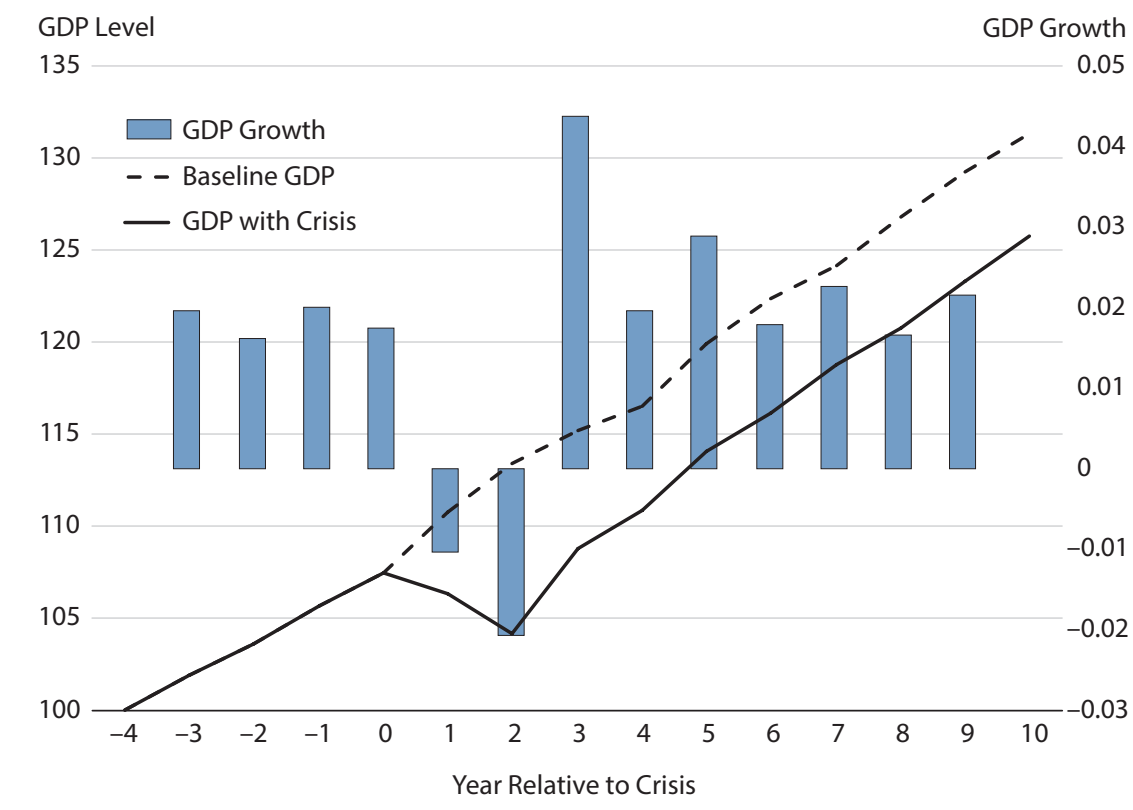

the effects are not permanent, then at some point the solid and dashed lines coincide and the effects of a crisis are reduced to zero, as is the area between the two lines beyond that point.

Furceri and Mourougane (2012) analyze OECD countries and compare actual output after a crisis with a measure of potential input. They estimate autoregressive equations and the implied impulse response functions, finding an average permanent reduction in GDP of 2 percent per year. Cerra and Saxena (2008) analyze data from over 120 countries and find evidence that effects of a financial crisis on GDP are barely reduced by 1 percentage point after 10 years, remaining at a level of 6 percent. These studies provide evidence for robust long-lasting effects. Given the empirical evidence, we think it is sensible to include long-lasting effects. However, as it is very difficult to statistically distinguish between permanent and highly persistent effects, we present results using an alternative assumption of a persistent-but-temporary effect that fades gradually over time.

We use the Gordon Growth Model to compute the present value of the long-term costs of a financial crisis as

$$
P V=\frac{\text { Initial GDP Impact }}{\text { Discount Rate }+ \text { Rate of Decay of Impact }} .
$$

This value is as of the beginning of the perpetuity flow, so we further discount it back to the beginning of the crisis. Cerra and Saxena (2008) find that the annual loss in GDP from a banking crisis shrinks by only 25 percent after 10 years, equivalent to an annual decay rate of 


\section{Table 4}

\section{Effect of Financial Crises on GDP (\%), by Horizon}

\begin{tabular}{ccccc} 
& \multicolumn{3}{c}{ Time since start of crisis } & Largest effect \\
\cline { 2 - 4 } Specification & 0 & 2.5 years & 5 years & -5.96 \\
\hline OLS & -2.08 & -4.72 & -4.61 & -4.07 \\
\hline GLS & -1.24 & -3.26 & -2.25 & -
\end{tabular}

NOTE: OLS, ordinary least squares; GLS, generalized least squares.

SOURCE: Romer and Romer (2015) and Table 2.

2.25 percent. There is considerable uncertainty around their point estimate, so we choose an annual decay rate of 5 percent to establish a larger range for our cost-of-crisis estimate.

Notice that in the growth formula, the present value is unaffected by whether an increase of a set amount impacts the discount rate or the decay rate. Therefore, in quantifying the costs of crises, we could think of this decay as equivalent to a 5 percent increase in the discount rate applied to the years following a crisis.

Short- and Medium-Term Severity of a Crisis. We use results from Romer and Romer (2015) of financial crises in advanced economies to estimate the short- and medium-term costs of a financial crisis in the United States. $\underline{21}$ The data are from 1967-2012 and include the 24 OECD members as of 1973 . The authors use narrative data from semiannual OECD reports to generate a continuous measure of the intensity of a crisis and run a regression with GDP growth, the state of a country's financial system, lags of both variables, and other controls. $\underline{22}$

Romer and Romer (2015) present estimates of the effect on GDP using a standard, ordinary least squares (OLS) regression, which weights each observation equally. They also present estimates using a statistically superior GLS approach, which provides less weight to observations from countries with a high variance of GDP growth. Most of these high-variance countries are smaller or less economically advanced. For example, the variances of GDP in Turkey, Iceland, and Ireland are much larger than that in the United States or other advanced countries. Such countries' economies are more influenced by international capital markets and/or sovereign risk. Nonetheless, data on financial crises are limited, and it is useful to include these countries in the analysis. As a compromise, we focus on Romer and Romer's GLS estimates, as they provide less weight to these high-variance countries that are arguably less comparable to the United States.

The authors give estimates of the reduction in GDP due to financial crises in advanced economies on a semiannual basis over five years. Their results with both GLS and OLS are shown in Table 4. $\frac{23}{3}$ Both specifications show that a relatively small effect, which is contemporaneous with a crisis, becomes larger in magnitude and reaches a peak after two-and-a-half years, slowly becoming smaller afterward.

Total Cost of a Crisis. We use a linear interpolation of Romer and Romer's (2015) GLS results for the effects of a financial crisis up to five years and assume a permanent reduction 
Figure 3

\section{Short- and Medium-Term Effects of a Financial Crisis on GDP}

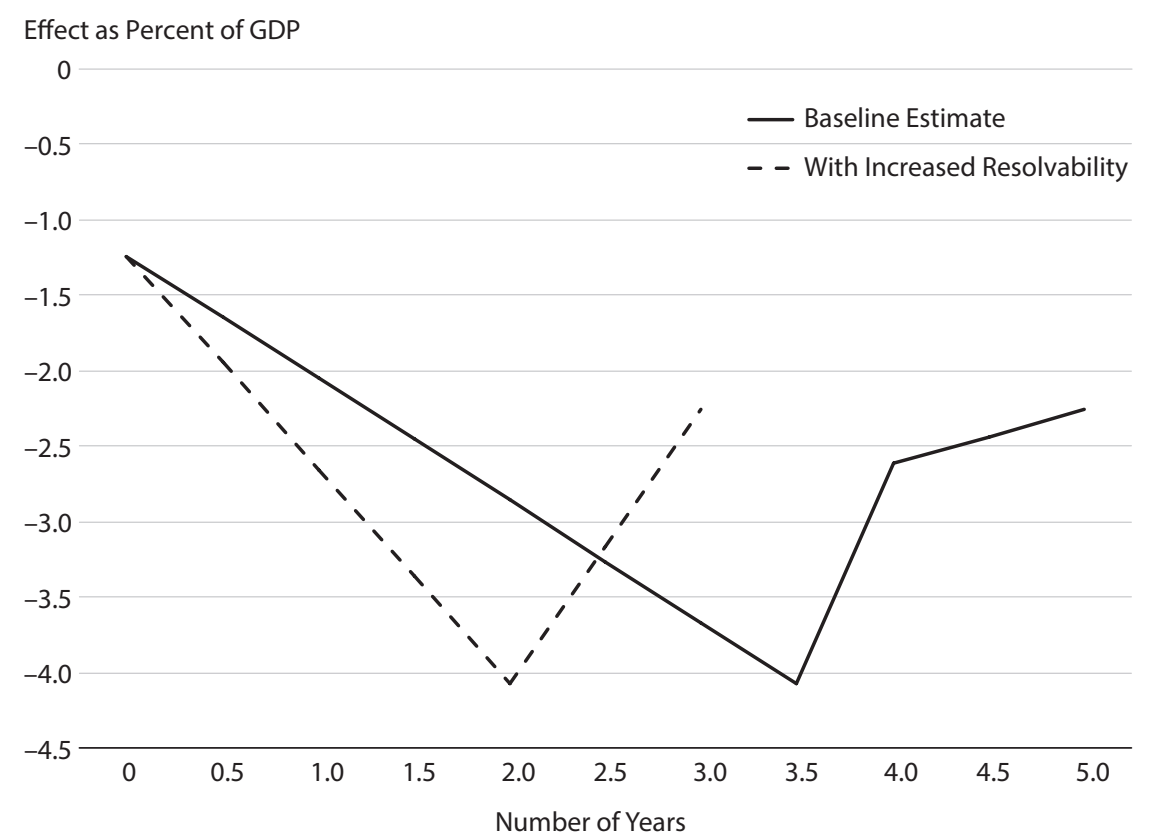

SOURCE: Baseline is a linear interpolation of Romer and Romer's (2015) Table 2 results with GLS estimation. "With increased resolvability" assumes that, per Homar and van Wijnbergen (2016), the duration of a crisis's effects is reduced. We assume the beginning, maximum, and final effects are as in the baseline, and again use linear interpolation to obtain results with prompt recapitalization requirements.

in GDP, as found by Furceri and Mourougane (2012), of 2 percent afterward. We also calculate the impact of an effect whose magnitude decays 5 percent a year.

As discussed below, we adjust these results for the effects of prompt recapitalization requirements and the increased resolvability of failing financial firms. To turn these estimates into a net present value, we need to apply a discount rate to future reductions in GDP. Standard asset pricing models imply that the real risk-free rate reflects the intertemporal preferences for the economy. We use the average real yield on 10-year Treasury bonds, or 2.7 percent. $\underline{24}$ The magnitude of the effect is quite sensitive to assumptions about decay (discount) rates, falling by more than half if we assume a 5 percent rate of decay. Improved resolvability requirements, discussed above, likely will cause future recapitalizations to happen more rapidly than was typical for advanced countries in the past. Research suggests that prompt recapitalization reduces the duration of financial crises. Homar and van Wijnbergen (2016) conclude that with prompt recapitalizations, the time to a GDP trough is two years rather than three-anda-half years, and the duration of effects is three years rather than five years. We maintain the Romer and Romer (2015) estimates of the peak and final semiannual costs of a financial crisis and calculate the revised costs given the shorter duration. Figure 3 shows the estimated semi- 


\section{Figure 4}

\section{Total and Marginal Benefits of Bank Capital, Relative to Current U.S. Average Tier 1 Capital Ratios (12.5 percent)}

\section{A. Total Benefits of Bank Capital}

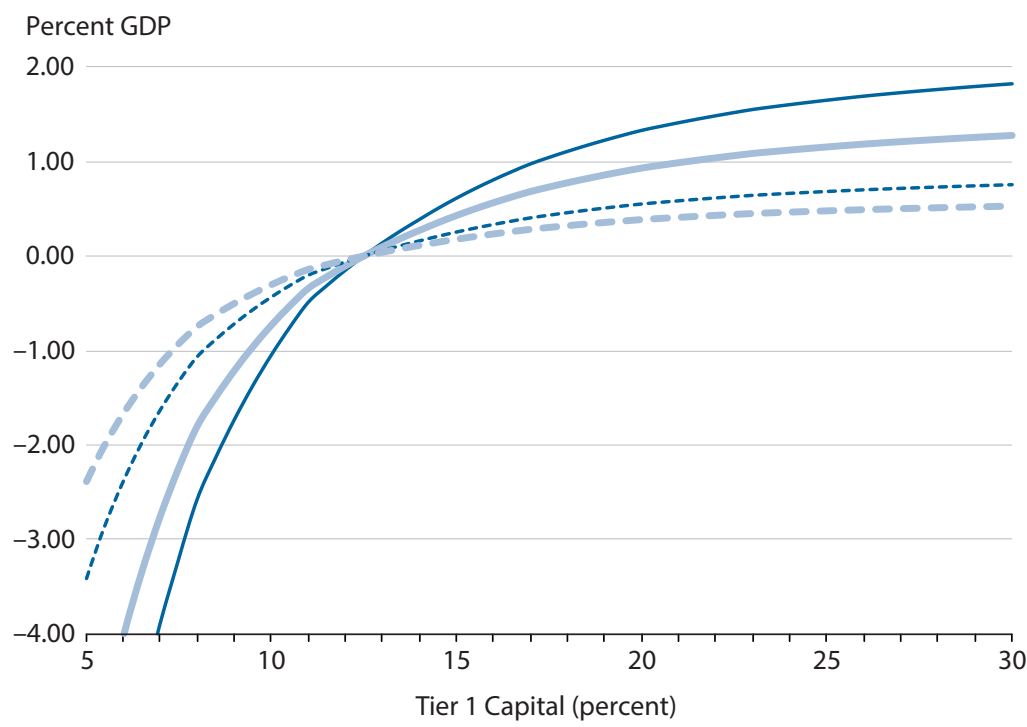

\section{B. Marginal Benefits of Bank Capital}

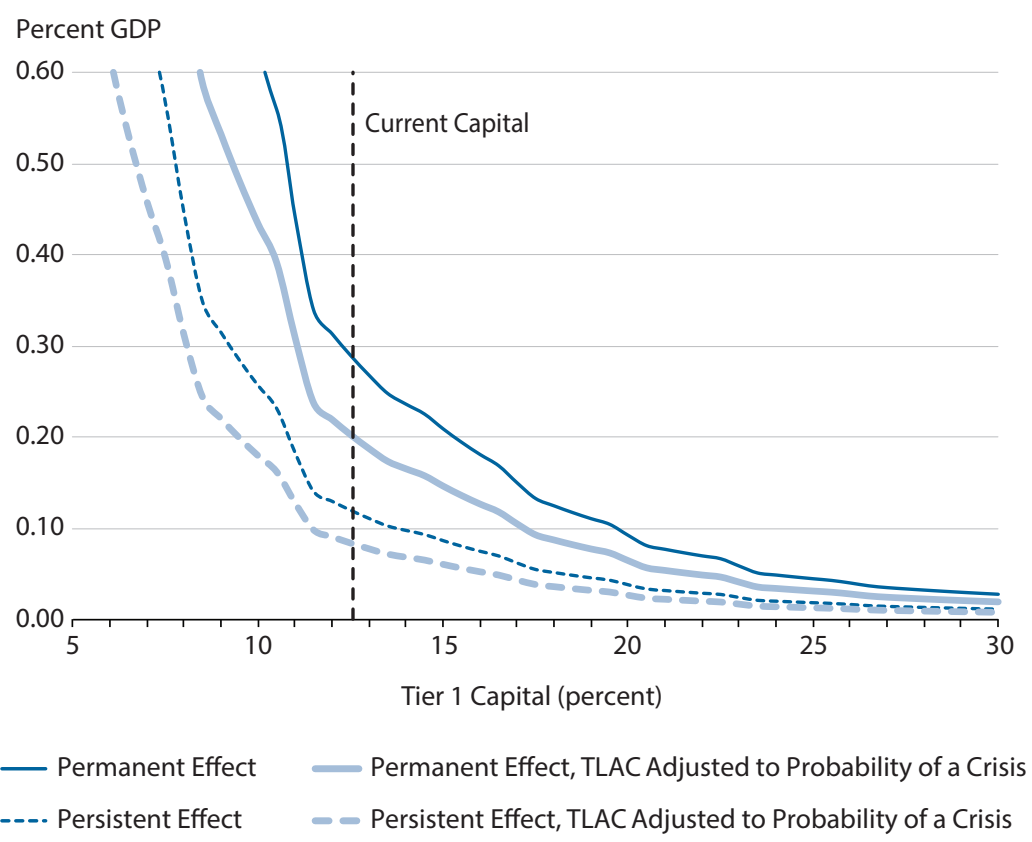




\section{Firestone, Lorenc, Ranish}

annual costs under this assumption. With the effects of increased resolvability, the estimated costs of financial crises fall by 3 to 4 percentage points of GDP. $\underline{25}$

Overall, assuming a permanent effect, we calculate the cost of a crisis as 99 percent of GDP. With a 5 percent rate of decay, the cost is 41 percent of GDP, a reduction of almost 60 percent. This wide range shows the importance of assumptions regarding the long-range effects of a crisis.

\subsection{Estimated Range of Benefits of Capital}

Within our framework, the benefits of bank capital equal the reduction in the probability that a financial crisis starts (estimated in Section 3.1), multiplied by the costs of the avoided financial crises (estimated in Section 3.2). Our estimates of each of these components vary because of different modeling assumptions. We either assume that increased resolvability has no effect or apply a 30 percent reduction in the probability of a financial crisis for it. We compute the cost of a crisis assuming that crises have either a permanent effect or a transitory, though highly persistent, effect on the level of GDP.

Figure 4 plots the range in benefits estimates due to this modeling variation. $\frac{26}{}$ Benefits are plotted relative to the benefits received at the current average level of Tier 1 capital ratios in the United States. Figure 4B, which presents marginal benefits, shows that at current capital levels, the marginal benefit of increasing capital ratios by 1 percentage point likely falls between 8 and 27 basis points of GDP per year. However, at lower capital levels, this marginal benefit is far higher. $\underline{27}$

\section{ECONOMIC COSTS OF BANK CAPITAL}

Increased bank capital reduces GDP through its impact on lending costs. Banks' weighted average cost of capital rises in response to higher capital, and some of this cost increase may be passed on to borrowers. A higher cost of credit discourages investment, thus decreasing the equilibrium level of GDP. In the macroeconomic model we use, long-term growth rates are unaffected by bank capital.

The first step in estimating the impact of bank capital on the level of GDP is to estimate how changes in capital affect the cost of loans. To do this, we estimate the impact of capital on a representative bank's weighted average cost of capital. Next, we calculate how much loan rates would have to change to offset these changes to the cost of capital. We assume that banks are able to pass either 50 or 100 percent of these changes on in the form of increased lending spreads.

Once we have estimated the impact of capital on lending costs, we use the Federal Reserve Board (FRB)/US macroeconomic model to assess the effect of these changes in lending costs on the equilibrium level of GDP. $\underline{28}$ The FRB/US macroeconomic model is a large-scale macro model used by Federal Reserve staff to track the evolution of the U.S. economy over time. The model is well documented and versions of it are freely available to the public. $\underline{29}$ It is used here as a baseline economic model to translate increased lending spreads into reduced GDP levels and follows previous work conducted by the Minneapolis Fed (2016). 


\section{Table 5}

\section{Studies Showing Evidence of Modigliani-Miller (MM) Offsets}

\begin{tabular}{lcc}
\multicolumn{1}{c}{ Study } & Geography of sample & MM offset \\
\hline Kashyap, Stein, and Hanson (2010) & U.S. & Partial \\
\hline Clark, Jones, and Malmquist (2015) & U.S. & $65-100 \%$ \\
\hline Junge and Kugler (2013) & Switzerland & $37 \%$ \\
\hline Miles et al. (2013) & U.K. & $45 \%$ \\
\hline Toader (2015) & Europe & $42 \%$ \\
\hline European Central Bank (2011) & International & $43 \%$ \\
\hline $\begin{array}{l}\text { NOTE: Clark, Jones, and Malmquist's (2015) results depend on the size of the bank and the time period. They find full } \\
\text { offsets for large banks since the 2007-09 Financial Crisis, and a 65 percent offset for banks with assets between \$100 } \\
\text { and \$200 billion. }\end{array}$ & \\
\hline
\end{tabular}

\subsection{Bank Capital Structure and the Modigliani-Miller Theorem}

A key driver of the cost of increased capital requirements is applicability of the ModiglianiMiller theorem (Modigliani and Miller, 1958) to U.S. banks. To the extent that the theorem applies, banks' funding costs are insensitive to their capital ratios, and the resulting economic costs of bank capital are reduced. Notable articles arguing that the theorem applies to banks include Miller (1995) and Admati et al. (2014). However, there are reasons, even in the presence of full Modigliani-Miller effects, that higher capital may result in higher funding costs. These are discussed in Elliott (2013), among other places. For example, the Modigliani-Miller theorem assumes that capital structure has no effect on taxes. Interest payments on debt are tax-deductible, serving as a "debt shield," while dividends are not, so higher equity means that banks pay more in taxes.

Ultimately, whether the theorem applies is an empirical question. A common approach is to consider the effects of changes in bank capital structure on the risk of bank equity, and hence its required return. If the risk of bank equity falls as the equity share of bank capital structure increases, then the required return on bank equity also falls, supporting the applicability of the Modigliani-Miller theorem. Kashyap, Stein, and Hanson (2010) find this predicted relationship for a panel of publicly traded U.S. banks for 1976-2008. Clark, Jones, and Malmquist (2015) suggest that the relevance of the Modigliani-Miller theorem for U.S. banks is more nuanced, depending on bank size and time. They find it holds most strongly for the largest banks, mainly because their debt is closer to riskless. Since the 2007-09 Financial Crisis, Clark, Jones, and Malmquist (2015) find that the Modigliani-Miller theorem holds for banks with assets of at least $\$ 100$ billion.

Other authors have studied European banks and find evidence of at least partial ModiglianiMiller offsets. We summarize them in Table 5. The body of empirical evidence strongly supports a partial Modigliani-Miller offset. We therefore assume a 50 percent Modigliani-Miller offset to rates of return throughout our estimates. 


\subsection{Increased Loan Rates}

We estimate the changes in banks' weighted average cost of capital resulting from changes in the amount of bank equity. We then assume that these changes in the cost of capital are offset by changes in banks' return on lending. The cost of increasing equity capital ratios by 1 percentage point equals the amount of capital raised, multiplied by the greater cost of equity capital - the return premium on equity over debt capital-adjusted for the Modigliani-Miller offset. It also includes the value of the tax shield provided by debt. The following equation represents this cost as a percentage of total assets:

$$
0.01 * \frac{R W A}{\text { Assets }} *\left[(1-M M) *\left(R^{E}-R^{D}\right)+R^{D} * t\right]
$$

where $R^{E}$ is the return on equity, $R^{D}$ is the return on debt, $M M$ is the degree of the ModiglianiMiller offset, and $t$ is the corporate tax rate.

For the average risk weight, RWA/assets, we use the asset-weighted average for large U.S. banks as of the end of 2015, which is 66 percent. $\frac{30}{\text { Substituting, this becomes }}$

$$
0.01 * 66 \% *\left[(1-M M) *\left(R^{E}-R^{D}\right)+R^{D} * t\right]
$$

To estimate the return on bank debt, $R^{D}$, we look at the past 15 years. We consider annual data on all U.S. top-tier bank holding companies with assets of at least $\$ 50$ billion in 2015 dollars. During the past 15 years, median interest costs were 1.61 percent on average. However, we consider recent, very-low interest rates to be a historic abnormality, so we use the precrisis (2001-06) period, for which median interest costs averaged 2.78 percent. $\underline{31}$

To estimate the return on bank equity, $R^{E}$, we apply the capital asset pricing model. We estimate the risk, or market betas, of bank equity using 15 years of data. We calibrate the model to an average risk-free rate of 2.78 percent and average excess market returns of 5.24 percent. We estimate a current daily market beta of 1.33 for domestic U.S. top-tier holding companies, based on data from 2010-15, implying an expected return for bank equity of 9.75 percent. $\underline{32}$ To complete the estimate, we use a corporate tax rate, $t$, of 43.7 percent. $\underline{33}$

We assume that half the Modigliani-Miller offset occurs:

$$
0.01 * 66 \% *[0.5 *(9.75 \%-2.78 \%)+2.78 \% * 43.7 \%] \text {. }
$$

We thus project an increase in asset return rates of 3.1 basis points per 1-percentage-point increase in capital ratios, of which 0.8 basis points is attributed to a reduced debt shield.

We assume this increase in cost is passed on entirely in the form of increased rates on loans. As loans currently comprise about 40 percent of bank assets, we divide the increase in the cost of capital by 40 percent for our estimate of the increase in loan costs, arriving at $0.00031 / 0.4$ or 7.8 basis points.

There are also reasons to think that banks may not be able to pass along 100 percent of any increased capital cost to borrowers. Competition with non-bank lenders and the public debt markets may make it difficult for banks to pass along increases in the cost of capital. Even 
without such competition, banks might increase revenue by reducing the cost of operations, decreasing interest expense, or finding revenue increases from business lines other than lending. $\frac{34}{}$ We consequently assume that, alternatively, banks can pass only half of their increased cost on to borrowers, which implies an increase in loan costs of 3.9 basis points per percentagepoint increase in equity capital. $\underline{35}$

\subsection{Translating Loan Rates into GDP}

We use the FRB/US model to translate increases in lending rates into a long-term effect on the level of GDP. In this model, lending rates have no effect on long-term growth rates. FRB/US is a large-scale model of the U.S. economy featuring optimizing behavior by households and firms, as well as detailed descriptions of monetary policy and the fiscal sector. $\mathrm{FRB} / \mathrm{US}$ has a neoclassical core that combines a production function with endogenous and exogenous supplies of production factors and key aspects of household preferences such as impatience. To account for cyclical fluctuations, the model features rigidities that apply to many decisions made by households and firms. The model does not explicitly include corporate loan spreads. Therefore, we use spreads on corporate bonds to model a shock to corporate lending rates and use spreads on home mortgages and auto loans to model a shock to consumer lending rates. $\underline{36}$

The model predicts that the effects on the equilibrium level of GDP from an increase in lending rates are approximately linear. A 1-basis-point increase in lending rates implies a decrease in the level of GDP of approximately 1.07 basis points..$^{37}$ Combining this with our estimated impact of bank capital on lending rates, we estimate that the effect of a 1-percentagepoint increase in capital ratios is a reduction in the level of long-term GDP of 8.3 basis points. If only half the cost is passed on in the form of higher rates on loans, the effect on long-term GDP is 4.2 basis points.

\section{ASSESSMENT OF NET BENEFITS}

Our framework for assessing the net benefits of bank capital requires that we estimate (i) the long-term effect of increased bank capital on the probability of a financial crisis in the United States, (ii) the net present cost of U.S. financial crises, (iii) the impact of capital on banks' lending spreads, and (iv) the effect of consequent higher lending rates on GDP. Because of uncertainty around the choice of modeling approach for several of these components, we report a range of estimates and refer the reader to Section 6 for a discussion of costs and benefits left out of our framework.

In Figure 5, we plot the range of economic costs and benefits that we model, relative to the costs and benefits of the current Tier 1 risk-based capital ratio of 12.5 percent for the average U.S. bank. Our low estimate of the benefits assumes that financial crises cause only gradually decaying reductions in GDP and that increased resolvability reduces the probability of crises by 30 percent. Our high estimate of the benefits assumes that financial crises result in permanent reductions in output and that increased resolvability affects only the costs, not the probability, of financial crises. Our low and high estimates of the costs vary only because 


\section{Figure 5}

\section{High and Low Estimates of the Costs and Benefits of Tier 1 Capital Relative to the Current Average U.S. Tier 1 Capital Ratio (12.5 percent)}

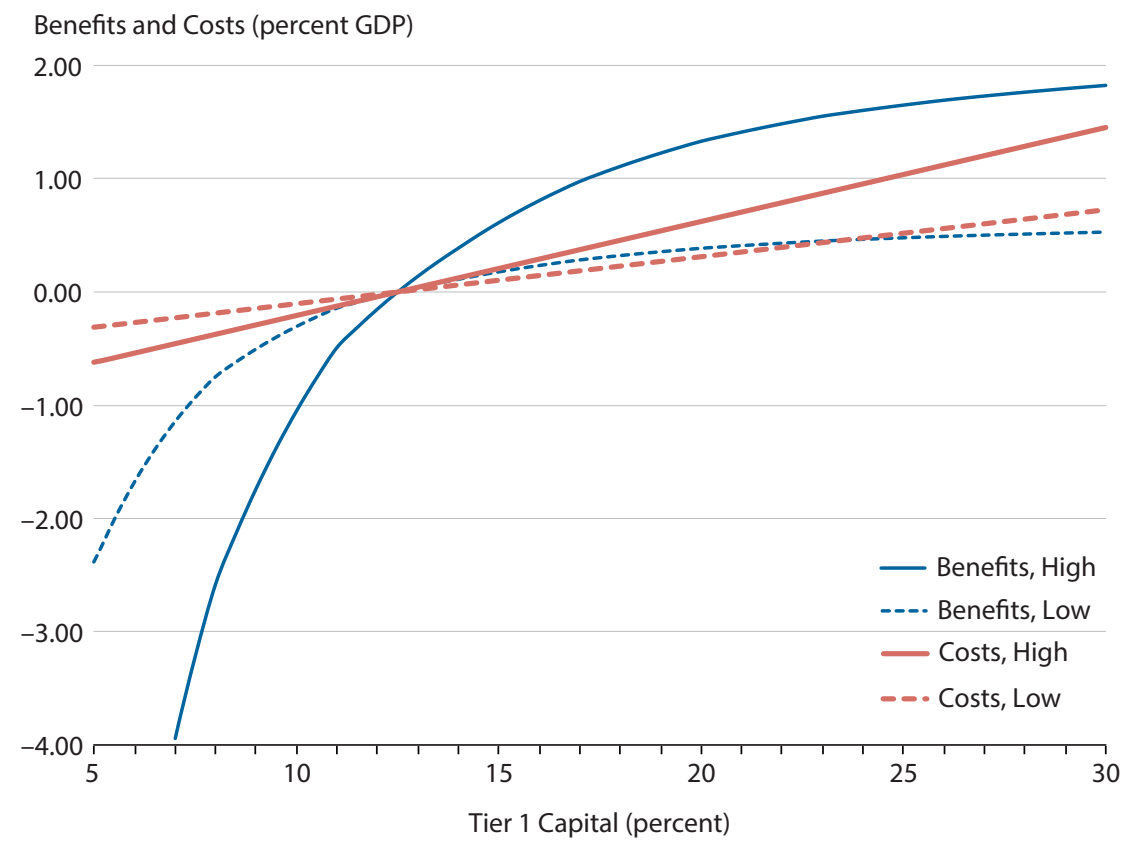

of the extent that increases in banks' cost of capital are passed on to borrowers. Both low and high estimates of the costs assume that 50 percent of the Modigliani-Miller effect applies and that lending costs affect only long-term GDP levels, not growth.

Figure 6 plots net benefits based on the cost and benefit curves from Figure 5. Figure 7 plots marginal net benefits or the net benefit of additional capital. Optimal capital levels are found where marginal net benefits equal zero. $\underline{38}$ These points are indicated by large diamonds. As mentioned above, banks generally hold significant capital above the minimum capital requirements, so optimal capital requirements would be lower than these levels.

The net benefit of additional capital beyond current levels is very sensitive to assumptions about both the costs and benefits of financial crises. For example, the assumption of low, instead of high, cost of capital levels increases the optimal level of capital by about 4 or 5 percentage points. The impact of using our high estimate of the benefits of capital is even larger at about 8 percentage points. However, in all cases the economic benefits of moderate increases in capital levels above current levels exceed the economic costs. At current levels of capital, this net benefit amounts to between approximately 0 and 25 basis points of annual GDP per percentage-point increase in additional required capital. Depending on the modeling approach, net benefits are maximized at capital ratios that vary from a low of 13 percent (high costs and low benefits) to 26 percent (low costs and high benefits). 


\section{Figure 6}

\section{Estimates of the Net Benefits of Tier 1 Capital Relative to the Current Average U.S. Tier 1 Capital Ratio (12.5 percent)}

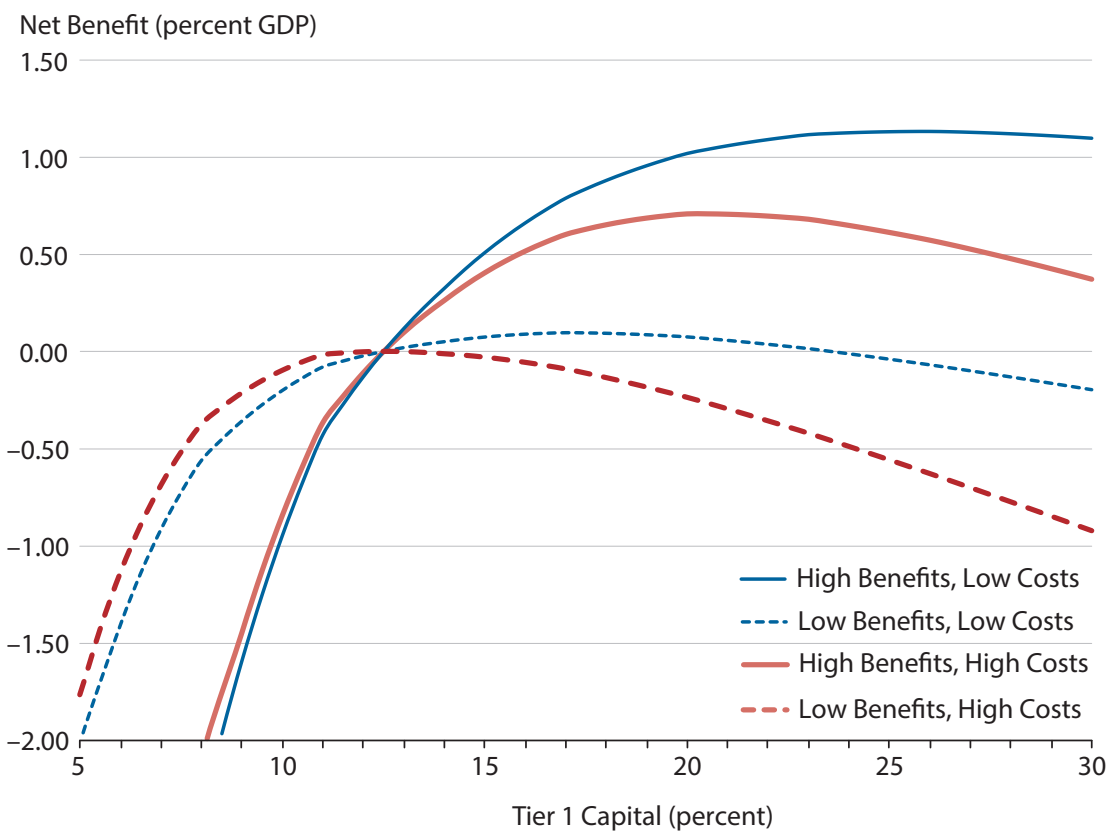

\section{Figure 7}

\section{Estimates of the Marginal Net Benefits of Tier 1 Risk-Based Capital}

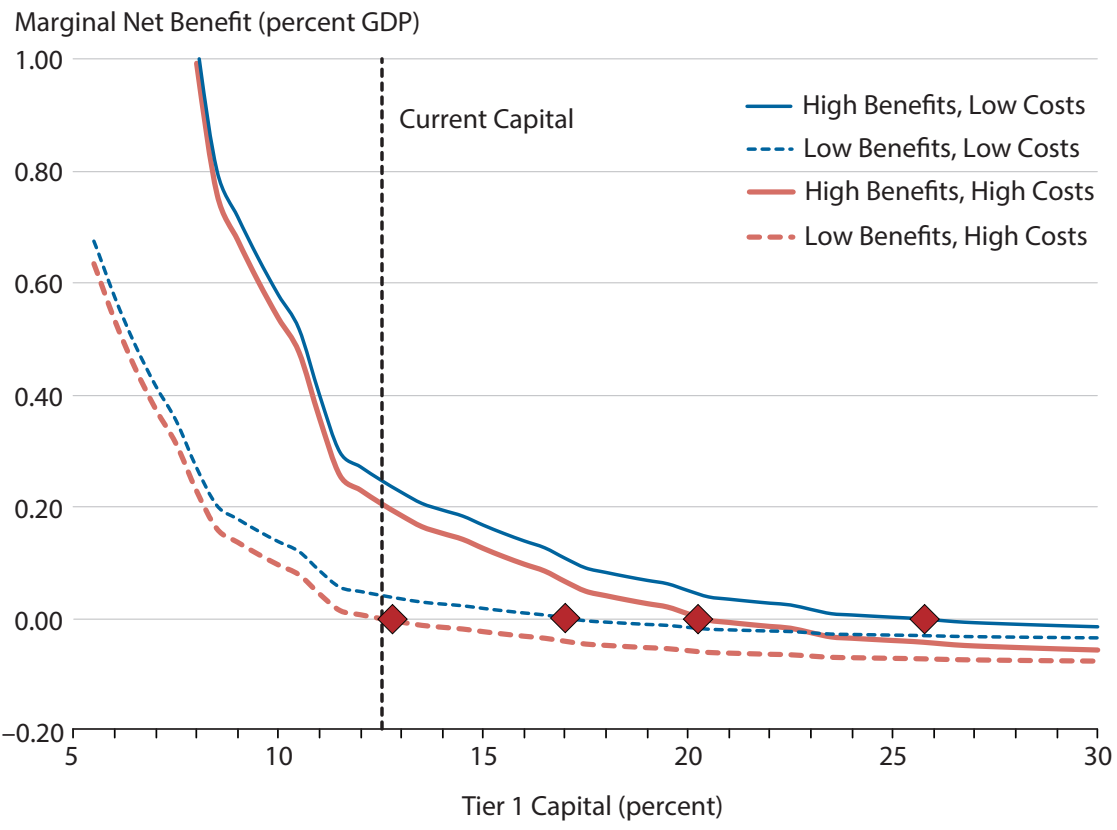




\section{Table 6}

\section{Optimal Tier 1 Capital from Other Impact Analyses}

\begin{tabular}{lc}
\multicolumn{1}{c}{ Study } & Optimal Tier 1 Capital \\
\hline This study & $13-26 \%$ \\
\hline Federal Reserve Bank of Minneapolis (2016) & $\sim 22 \%$ \\
\hline Dagher et al. (2016) & $15-23 \%$ \\
\hline Brooke et al. (2015) & $10-14 \%$ \\
\hline Miles et al. (2013) & $\sim 20 \%$ \\
\hline BCBS (2010) & $9-15+\%$ \\
\hline NOTE: The BCBS (2010) optimal Tier 1 capital represents a Basel II TCE/RWA ratio. We \\
calculate the equivalent Basel III Tier I/RWA ratio as 9.3 percent to 15.5+ percent.
\end{tabular}

Table 6 compares these estimates of optimal capital levels with those estimated in other studies. Only the Brooke et al. (2015) analysis yields optimal capital requirement levels that are significantly lower. This is primarily due to the large size of the reduction to both probability and costs of financial crises that the authors apply for the presence of TLAC regulations.

\section{OTHER ECONOMIC COSTS AND BENEFITS OF BANK CAPITAL}

There are a number of economic costs and benefits of bank capital not explicitly captured in our results for a variety of reasons, including availability of data, required assumptions, and general feasibility. We will now discuss these costs and benefits and the expected impact they could have on capital.

\subsection{Implications for a Risk-Averse World}

A better capitalized banking system reduces the volatility of economic cycles, particularly where capital requirements include a countercyclical buffer. Using a DSGE model, BCBS (2010) suggests that output volatility decreases by a bit over 1 percent for each percentagepoint increase in Tier 1 capital. $\underline{39}$ Risk-averse people prefer reduced consumption volatility and especially dislike large negative shocks. For example, suppose a country produces one unit of output per year, except during crises when output is instead 0.9 units. A hypothetical consumer of this output with a typical utility function would be willing to forgo up to about 0.4 percent of the expected output in return for reducing the probability of crises from 4 percent to 1 percent. $\frac{40}{}$ This consumer might be willing to give up significantly more to avoid crises if, for example, crises were associated with greater idiosyncratic volatility (e.g., likelihood of job loss) or the consumer has large inflexible expenses (e.g., housing payments).

In addition, the macrofinance literature suggests that "rare disasters," such as financial crises, may explain much of the risk premia that risk-averse investors require (e.g., Rietz, 1988, and Barro, 2006). A reduction in the probability of a financial crisis could thereby reduce the cost of capital across the economy and increase output. 


\subsection{Cross-Border Externalities}

We have attempted to quantify only those costs and benefits of higher capital for U.S. banks that accrue within the United States. Improved stability of the U.S. financial system may also improve the stability of foreign financial systems. Kaminsky, Reinhart, and Vegh (2003) describe financial crises whose effects were felt across international borders even where the linkages between countries are weak, a phenomenon known as "contagion." They also provide a review of the theoretical literature on why contagion may occur. Most of their analysis focuses on less-developed economies. Kalemli-Ozcan, Papaioannou, and Perri (2013) describe how the 2007-09 Financial Crisis spread across U.S. borders. By decreasing the probability of domestic financial crises, higher U.S. bank capital also decreases the probability of overseas crises.

\subsection{Migration of Financial Intermediation}

To the extent that higher bank capital increases lending costs for banks, financial intermediation could migrate out of the regulated financial sector. This has an ambiguous effect on optimal capital levels. Benefits are reduced as systemic risks become less effectively controlled, but costs also decline as competition provided by non-regulated intermediation decreases lending costs. Pozsar et al. (2013) provide an overview of the institutional framework of the shadow banking system. Plantin (2014) presents a general equilibrium model that demonstrates the risk of banks shifting assets to less-regulated money market funds. Harris, Opp, and Opp's (2014) analysis of a general equilibrium model with bank and non-bank lenders shows that, depending on the size of the increase in capital, the presence of competing shadow banks can be helpful or harmful because of changes in the nature of projects that receive funding.

\subsection{Interaction of Costs of Higher Capital with TLAC and Liquidity Requirements}

The greater reliance on long-term unsecured debt due to TLAC likely increases banks' cost of capital. The liquidity rules are likely to also increase banks' reliance on longer-term funding, which would also raise banks' cost of capital. As we use a cost of capital that neglects the impact of future effects of liquidity and TLAC requirements to calculate the cost of increasing equity financing, we may overstate the effect of higher equity capital on banks' cost of capital. Such adjustments would likely decrease the costs of higher capital.

\subsection{Transitional Costs}

We exclusively analyze the long-term economic costs of bank capital. Kiley and Sim (2010) analyze the cost of transition to higher capital levels. They assume that banks achieve these levels through raising new equity, reducing dividends, and reducing lending. Their estimates, like ours, are characterized by considerable uncertainty and imply a reduction in GDP between 0.5 percent and 3 percent of GDP for a 2-percentage-point increase in capital ratios. The magnitude of their results is partially due to their assumption that when banks reduce lending, there is no other substitute for financing, leading to a credit crunch. This assumption may be 
unrealistic where there is a bond market and non-bank lenders, and thus their results likely represent an upper bound on transitional costs. Their analysis also shows that the magnitude of the effect on GDP is reduced when banks are given a long period to comply with new requirements. Including such transitional costs would decrease the net benefits of higher capital.

\section{CONCLUSION}

This article assesses the long-term net benefits of the level of bank capital to provide an estimated range of optimal Tier 1 risk-based capital levels. We provide estimates of optimal capital levels under a variety of assumptions about the costs of financial crises and the extent to which lending rates could rise in response to higher levels of bank capital. When using a high estimate of the costs and low estimate of the benefits of capital, we find an optimal capital ratio around 13 percent, which is close to the current average capital ratio of 12.5 percent for U.S. banks. When using higher estimates of the benefits of capital, we find optimal Tier 1 risk-based capital ratios are approximately 26 percent. As banks generally hold substantial buffers above the minimum requirements, optimal capital requirements would be lower. 11

This range of estimates is limited by a framework that includes only two channels by which bank capital affects the real economy. Optimal capital levels may be even higher in a framework that accounts for the preferences of risk-averse consumers or the international benefits of financial stability, and they are likely lower when accounting for the cost of a transition to higher capital levels or allowing lending costs to affect long-term growth rates. 


\section{APPENDIX}

\section{Liquidity Requirements Adjustment to Simulation-Based Estimates of the Probability of a Financial Crisis}

First, we construct a set of proxies for compliance with the LCR, as these figures are generally not available historically.. We identify a cross section of 12 large U.S. banks in 2012 for which both LCR and liquid asset share (from Bankscope) are available. The correlation of these two variables is significant (about 0.52), and a least squares regression of LCR on liquid asset share (without an intercept) yields: LCR $=2.55$ *liquid_asset_share. For each of these 12 observations, we then estimate the liquid asset share required to set LCR equal to one (the required level $)$ as required_liquid_asset_share $=(1-$ LCR $) / 2.55$. These 12 values are proxies for the liquid asset share equivalent to LCR compliance.

Next, we estimate the historical relationship between the (lagged) liquid asset share of a bank and the magnitude of banks' losses. We run least squares regressions of the log magnitude of losses (relative to RWA) on log liquid assets, alternately controlling for (lagged) log assets and bank type in addition to log assets. The estimated coefficient on log liquid assets varies from -0.095 to -0.107 , so we use -0.10 as our estimate of the impact of log liquid assets on $\log$ loss magnitude. $\underline{43}$

\section{Table A1}

\section{Example of Liquidity Requirement Adjustments to Net Income Draws}

\begin{tabular}{lccc} 
& U.S. Bank A & U.S. Bank B & U.S. Bank C \\
\hline Randomly drawn net income/RWA & -0.12 & -0.11 & 0.09 \\
\hline $\begin{array}{l}\text { Liquid asset share } \\
\text { (from same random bank) }\end{array}$ & $20 \%$ & $40 \%$ & $10 \%$ \\
\hline Randomly assigned LCR proxy & $40 \%$ & $20 \%$ & $35 \%$ \\
\hline Net income multiplier & $0.93=(40 \% / 20 \%)^{-0.1}$ & 1 (bank already LCR compliant) & 1 (net income is positive) \\
\hline Net income/RWA to use & $-0.1116=0.93 *-0.12$ & -0.11 & 0.09 \\
\hline
\end{tabular}

To integrate these findings within the simulations described above, we draw the liquid asset share in addition to net income (relative to RWA) from the banks in each country-year scenario. We also randomly assign one of the 12 proxies for LCR compliance based on liquid asset share to each bank. Then, if the net income drawn is negative and the liquid asset share drawn is less than the assigned LCR proxy, net income is adjusted toward zero based on the relationship of log liquid assets to log loss magnitude estimated above. Table A1 provides three examples of this procedure. Bank A receives a draw of negative net income from some bank X with relatively low liquid assets. Based on the randomly assigned LCR proxy of 40 percent, bank X's log liquid asset share would need to be higher by $\ln (40$ percent $)-\ln (20$ percent) $=0.693$ to have been LCR compliant. The regression of log net losses (relative to RWA) above implies, in turn, that log losses would have been lower by $-0.1 * 0.693=-0.0693$, or 


\section{Firestone, Lorenc, Ranish}

that losses would have been 93.3 percent as large. In this case, we apply this modifier to the losses before computing the size of any bank-specific or aggregate shortfall. The table shows that no such modifier is applied when the draw comes from either a bank deemed already LCR compliant (as in the case of Bank B) or the net income drawn is positive (as in the case of Bank C).

\section{REFERENCES}

Admati, A.; DeMarzo, R.P.; Hellwig, M. and Pfleiderer, P. "Fallacies and Irrelevant Facts in the Debate on Capital Regulation." Central Banks at a Crossroads: Europe and Beyond. London: Anthem Press, 2014.

Afonso, G.; Santos, J. and Traina, J. “Do 'Too-Big-to-Fail' Banks Take on More Risk?" Federal Reserve Bank of New York, Economic Policy Review, 2014; https://www.newyorkfed.org/medialibrary/media/research/epr/2014/1412afon.pdf.

Barro, R. "Rare Disasters and Asset Markets in the Twentieth Century." Quarterly Journal of Economics, 2006, 121(3), pp. 823-66; https://doi.org/10.1162/qjec.121.3.823.

Basel Committee on Banking Supervision. "An Assessment of the Long-Term Economic Impact of Stronger Capital and Liquidity Requirements." 2010; https://www.bis.org/publ/bcbs173.pdf.

Brooke, M.; Bush, O.; Edwards, R.; Ellis, J.; Francis, B.; Harimohan, R.; Neiss, K. and Siegert, C. "Measuring the Macroeconomic Costs and Benefits of Higher U.K. Bank Capital Requirements." Financial Stability Paper No. 35, Bank of England, 2015; https://www.bankofengland.co.uk/financial-stability-paper/2015/measuring-the-macroeconomic-costs-and-benefits-of-higher-uk-bank-capital-requirements.

Brunnermeier, M. and Pedersen, L. "Market liquidity and Funding Liquidity." Review of Financial Studies, 2009, 22(6), pp. 2201-38; https://doi.org/10.1093/rfs/hhn098.

Cerra, V. and Saxena, S. "Growth Dynamics: The Myth of Economic Recovery." American Economic Review, 2008, 98(1), pp. 439-57; https://doi.org/10.1257/aer.98.1.439.

Cifuentes, R.; Ferrucci, G. and Shin, H.S. "Liquidity Risk and Contagion." Journal of the European Economic Association, 2005, 3(2-3), pp. 556-66; https://doi.org/10.1162/jeea.2005.3.2-3.556.

Clark, B.; Jones, J. and Malmquist, D. "Leverage and the Weighted-Average Cost of Capital for U.S. Banks." Working Paper, SSRN, 2015; https://doi.org/10.2139/ssrn.2491278.

Dagher, J.; Dell'Ariccia, G.; Laeven, L.; et al. "Benefits and Costs of Bank Capital." Staff Discussion Note, International Monetary Fund, 2016; https://www.imf.org/external/pubs/ft/sdn/2016/sdn1604.pdf.

Demirgüç-Kunt, A.; Detragiache, E. and Gupta, P. "Inside the Crisis: An Empirical Analysis of Banking Systems in Distress." Journal of International Money and Finance, 2006, 25, pp. 702-18; https://doi.org/10.1016/j.jimonfin.2006.04.004.

Elliott, D. “Higher Bank Capital Requirements Would Come at a Price." Brookings Report, 2013; https://www.brookings.edu/research/higher-bank-capital-requirements-would-come-at-a-price/.

European Central Bank. "Common Equity Capital, Banks' Riskiness and Required Return on Equity." Financial Stability Review, December 2011, pp. 125-31.

Federal Reserve Bank of Minneapolis. "The Minneapolis Plan to End Too Big to Fail." 2016; https://www.minneapolisfed.org/ /media/files/publications/studies/endingtbtf/the-minneapolis-plan/the-minneapolis-plan-to-end-too-big-to-fail-2016.pdf.

Financial Stability Board. "Assessing the Economic Costs and Benefits of TLAC Implementation." Bank for International Settlements, 2015; $\underline{\text { https://www.bis.org/publ/othp24.pdf. }}$

Furceri, D. and Mourougane, A. "The Effect of Financial Crises on Potential Output: New Empirical Evidence from OECD Countries." Journal of Macroeconomics, 2012, 34(3), pp. 822-32; https://doi.org/10.1016/j.jmacro.2012.05.010. 
Harris, M.; Opp, C. and Opp, M. “Higher Capital Requirements, Safer Banks? Macroprudential Regulation in a Competitive Financial System." Working Paper, SSRN, 2014; http://dx.doi.org/10.2139/ssrn.2181436; https://doi.org/10.2139/ssrn.2181436.

Hoggarth, G.; Reis, R. and Saporta, V. "Costs of Banking System Instability: Some Empirical Evidence." Journal of Banking \& Finance, 2002, 26, pp. 825-55; https://doi.org/10.1016/S0378-4266(01)00268-0.

Homar, T. and van Wijnbergen, S.J.G. "Bank Recapitalization and Economic Recovery after Financial Crises." Journal of Financial Intermediation, 2016, 32, pp. 16-28; https://doi.org/10.1016/j.jfi.2016.11.004.

Hutchison, M. and Noy, L. "How Bad Are Twins? Output Costs of Currency and Banking Crises." Journal of Money, Credit, and Banking, 2005, 37(4), pp. 725-51; https://doi.org/10.1353/mcb.2005.0043.

Junge, G. and Kugler, P. "Quantifying the Impact of Higher Capital Requirements on the Swiss Economy." Swiss Journal of Economics and Statistics, 2013, 149(3), pp. 313-356; https://doi.org/10.1007/BF03399394.

Kalemli-Ozcan, S.; Papaioannou, E. and Perri, F. "Global Banks and Crisis Transmission." Journal of International Economics, 2013, 89(2), pp. 495-510; https://doi.org/10.1016/j.jinteco.2012.07.001.

Kaminsky, Graciela L.; Reinhart, C.M. and Vegh, C.A. "The Unholy Trinity of Financial Contagion." Journal of Economic Perspectives, 2003, 17(4), pp. 51-74; https://doi.org/10.1257/089533003772034899.

Kashyap, A.K.; Stein, J.C. and Hanson, S. "An Analysis of the Impact of 'Substantially Heightened' Capital Requirements on Large Financial Institutions." Booth School of Business, University of Chicago, Mimeo, 2010; https://faculty.chicagobooth.edu/anil.kashyap/research/papers/an analysis of the impact of substantially heightened-Capital-Requirements-on-Financial-Institutions.pdf.

Kiley, M. and Sim, J. "Technical Background Report: An Assessment of the Macroeconomic Transition Costs Associated with Higher Levels of Capital at Financial Institutions in the United States." Unpublished Manuscript, Board of Governors of the Federal Reserve System, 2010.

Laeven L. and Valencia, F. "Systemic Banking Crises Database: An Update." Working Paper No. 12/163, International Monetary Fund, 2012; https://doi.org/10.5089/9781475505054.001.

Malherbe, F. "Self-Fulfilling Liquidity Dry-Ups." Journal of Finance, 2014, 69(2), pp. 947-70; https://doi.org/10.1111/jofi.12063.

Marques, L.B.; Correa, R. and Sapriza, H. "International Evidence on Government Support and Risk Taking in the Banking Sector." Working Paper No. 13/94, International Monetary Fund, 2013; https://doi.org/10.5089/9781484309346.001.

Miles, D.; Yang, J. and Marcheggiano, G. “Optimal Bank Capital.” Economic Journal, 2013, 123(657), pp. 1-37; https://doi.org/10.1111/j.1468-0297.2012.02521.x.

Miller, M.H. "Do the M\&M Propositions Apply to Banks?" Journal of Banking \& Finance, 1995, 19, pp. 483-89; https://doi.org/10.1016/0378-4266(94)00134-O.

Modigliani, F. and Miller, M.H. "The Cost of Capital, Corporation Finance and the Theory of Investment." American Economic Review, 1958, 48(3), pp. 261-97.

Philippon, T. and Reshef, A. "Wages and Human Capital in the U.S. Finance Industry: 1909-2006." Quarterly Journal of Economics, 2012, 127(4); https://doi.org/10.1093/qje/qjs030.

Plantin, G. "Shadow Banking and Bank Capital Regulation." Review of Financial Studies, 2014, 28(1), pp. 146-75; https://doi.org/10.1093/rfs/hhu055.

Pozsar, Z.; Adrian, T.; Ashcraft, A. and Boesky, H. "Shadow Banking," Federal Reserve Bank of New York, Economic Policy Review, 2013, 458, pp. 3-9.

Rietz, T. "The Equity Risk Premium: A Solution." Journal of Monetary Economics, 1988, 22, pp. 91-115; https://doi.org/10.1016/0304-3932(88)90172-9.

Romer, C. and Romer, D. "New Evidence on the Impact of Financial Crises in Advanced Countries." Working Paper No. 21021, National Bureau of Economic Research, 2015; https://doi.org/10.3386/w21021.

Shleifer, A. and Vishny, R. "Fire Sales in Finance and Macroeconomics." Journal of Economic Perspectives, 2011, 25(1), pp. 29-48; https://doi.org/10.1257/jep.25.1.29. 


\section{Firestone, Lorenc, Ranish}

Toader, O. "Estimating the Impact of Higher Capital Requirements on the Cost of Equity: an Empirical Study of European Banks." International Economics and Economic Policy, 2015, 12(3), pp. 411-436;

https://doi.org/10.1007/s10368-014-0303-x.

\section{NOTES}

1 Throughout the article, unless otherwise noted, we refer to capital as Tier 1 risk-based capital.

2 The low estimate of benefits also incorporates an assumption that total loss-absorbing capacity (TLAC) regulations independently reduce the probability of a financial crisis by 30 percent. Our high estimate of benefits assumes that TLAC regulations reduce only the costs of financial crises, not their probability.

$\underline{3}$ Brooke et al. (2015) use other methods to adjust for the presence of such countries in the sample.

4 See www.federalreserve.gov/newsevents/press/bcreg/20151030a.htm for more information on long-term debt and TLAC requirements. See www.federalreserve.gov/bankinforeg/resolution-plans.htm for more information on living wills. See www.fdic.gov/regulations/laws/federal/2011/11finaljuly15.pdf for more information on the orderly liquidation authority.

5 See Shleifer and Vishny (2011) for a review of the literature on asset fire sales. See Brunnermeier and Pedersen (2009) for a discussion of the destabilizing link between market and funding liquidity.

6 See www.federalreserve.gov/newsevents/press/bcreg/20140903a.htm for more information on the LCR.

7 Romer and Romer (2015) include an extensive comparison of their definition with that in Laeven and Valencia (2012). They are almost equivalent in identifying if crises occur but have a few differences with regard to crises start dates.

8 We apply a 50 percent weight to our bottom-up approach and a 25 percent weight to each of the two models in our top-down approach.

9 The sample includes Australia, Austria, Belgium, Canada, Denmark, Finland, France, Germany, Greece, Iceland, Ireland, Italy, Japan, Luxembourg, the Netherlands, New Zealand, Norway, Portugal, Spain, Sweden, Switzerland, Turkey, the United Kingdom, and the United States.

10 We exclude 30 country-years where coverage appears particularly incomplete and/or includes banks representing less than $\$ 10$ billion in aggregate total assets.

11 In contrast to our approach, the Brooke et al. (2015) impact analysis pools country-years into just the following two scenarios: one where credit/GDP and equity volatility are high and one where they are not.

12 To account for the average difference between Basel III risk weights and Basel I and II risk weights, we increase RWA for all years prior to 2011 by the increase in U.S. average risk weights for 2011-15 (about 11 percent). For 2012-14, we increase RWA by the increase in U.S. average risk weights between that year and 2015.

13 We exclude small banks from the distribution of net income we draw from, as this distribution may be different for small banks. We define the cutoff between small and large banks so that 90 percent of each country's financial system assets in each year are within "large" banks. Across countries, we have an average of about 915 large banks per year.

14 When using a different threshold, as is done by Brooke et al. (2015), additional adjustments are required to match the historical frequency of financial crises.

15 The Financial Stability Board analysis uses 30 percent as a baseline estimate, but also provides a range of estimates for the impact of TLAC ranging from under 10 percent to over 40 percent.

16 We omit country-years where there is an ongoing crisis because we are interested in predicting the probability of a financial crisis starting. This probability is implicitly conditional on a financial crisis not yet having occurred.

17 We used the Chicago Board Options Exchange $\mathrm{VXO}^{\oplus}$ volatility index prices until the $\mathrm{VIX}^{\circledR}$ index became available in 1990. Historical VIX ${ }^{\circledR}$ data is available at www.cboe.com/products/vix-index-volatility/vix-options-and-futures/ vix-index/vix-historical-data. 
18 We follow Financial Stability Board (2015), which relies on work by Afonso, Santos, and Traina (2014) and Marques, Correa, and Sapriza (2013) to estimate that TLAC reduces the probability of a financial crisis by 30 percent.

19 Note that Tier 1 capital is not statistically significant in specification (1). We retain it because it incorporates much more data. If we were to use just specification (2), it would slightly increase the lower bound of our estimate of the optimal capital range to 14 percent and lower the upper bound of the range to 22 percent.

20 Defining the end of a crisis's effects as when the economy exits a recession would give the same results. If we define the temporary effects as occurring when the economy reaches its pre-crisis growth path, the crisis would end when the two lines intersect.

$\underline{21}$ There are other studies measuring the overall short- and medium-term costs of a financial crisis. Examples include Hoggarth, Reis, and Saporta (2002), Hutchison and Noy (2005), and Demirgüç-Kunt, Detragiache, and Gupta (2006). We use results from Romer and Romer (2015) because they focus on advanced countries and are thus most relevant to the United States. Romer and Romer (2015) are also unique in that they provide estimates of the semiannual dynamics of the effect on GDP, rather than a single aggregated number. A further advantage is that they incorporate results from the 2007-09 Financial Crisis. The dynamics allow a more credible analysis of the effects of shortening crises through prompt recapitalization.

$\underline{22}$ Note that our analysis of the probability of a crisis uses the definition in Laeven and Valencia (2012). See section I.D of Romer and Romer (2015) for a comparison of financial crises identified by their method and an updated version of the data used by Laeven and Valencia (2012). The two are almost identical. Furceri and Mourougane (2012) use the same definition as Laeven and Valencia (2012).

$\underline{23}$ These numbers are calibrated to represent a "moderate" crisis. The last time they designated the United States as having been in such a crisis state was the second half of 2009.

$\underline{24}$ We use all monthly data for 1962-2016 and calculate inflation from the CPI for all urban consumers. Data were obtained from the Federal Reserve Bank of St. Louis Economic Research website at https://research.stlouisfed.org/.

$\underline{25}$ While this may seem small, given that U.S. GDP in 2015 was $\$ 18.2$ trillion, this translates into a reduction in cost of $\$ 546$ to $\$ 728$ billion.

$\underline{26}$ To remove minor non-monotonicities in the plot of marginal benefits, we approximate the probability of a financial crisis generated by the bottom-up approach by a piecewise log function with segments that are 2 percentage points wide. This adjustment has little effect on the level of curves or the estimated optimal level of capital.

27 The marginal benefit of capital is "lumpy" due to lumpiness in distribution of the net income implicit in the bottom-up approach. For example, the marginal benefit is slightly higher at a 21 percent capital ratio than at a 20 percent capital ratio, as there are more scenarios where a roughly 21 percent capital ratio is just barely required to avoid crisis. Miles, Yang, and Marcheggiano (2013) also look at a model where the presence of rare, but very large, shocks to capital means that the marginal benefit of capital is not decreasing everywhere.

28 We thank Michael Siemer for using FRB/US to calculate the effect of an increase in lending costs on the level of GDP.

$\underline{29}$ For more information on the FRB/US model, see the Board of Governors of the Federal Reserve System's website at www.federalreserve.gov/econresdata/notes/feds-notes/2014/a-tool-for-macroeconomic-policy-analysis.html.

30 Many recent changes have affected banks' asset composition and RWA calculations in recent years, including the implementation of Basel III, the Volcker rule, and liquidity and TLAC regulations. Therefore we use data on both RWA/assets, assets/loans, and interest expense from December 2015, the most recent full year for which data are available. Neither the interest rate environment nor regulations governing RWA calculations have changed since then in a way that would significantly affect our conclusions.

31 Kayshap, Stein, and Hanson (2010) assume that additional equity will displace either long-term or short-term debt. TLAC and liquidity requirements mean that banks are now less free to adjust their liability composition. Thus, we use the average liability cost.

$\underline{32}$ We use data starting in 2010 for calculating beta because the large number of mergers and acquisitions following a crisis would muddy the analysis prior to that date.

33 We follow Clark, Jones, and Malmquist (2015) in assuming a Delaware residence. Delaware has a tax rate of 8.37 percent, and the federal corporate tax rate is 35 percent. Only South Dakota and Wyoming have no corporate income or gross receipts tax. State corporate income taxes range from 4 percent to 12 percent for 2016 . See http://taxfoundation.org/article/state-corporate-income-tax-rates-and-brackets-2016. 


\section{Firestone, Lorenc, Ranish}

34 Philippon and Reshef (2012) show that wages in the financial sector from 1990 onward earned a premium over other sectors. This premium grew over time and cannot be fully explained by risk or technological change. This research suggests that cost reductions are feasible.

35 If only half the increased cost is passed on in the form of higher loan rates, banks might respond to increased costs in other ways, such as focusing more on higher-yield, and thus risky, lending. Banks might also raise fees for other services in a manner that could create distortions. To our knowledge, there is no adequate empirical basis for modeling such effects.

36 Most of the effect on GDP is from an increase in corporate lending rates. To the extent that rate increases are limited to other loans, we may be overstating the effects.

37 This is slightly different than the results calculated by the Federal Reserve Bank of Minneapolis (2016). The Minneapolis Fed (2016) calculates changes from a long-term baseline, while we use the present-day scenario.

$\underline{38}$ The irregularities in the marginal benefit curve occur because the density of loss severities in the historical data is not steadily decreasing as loss severity increases.

39 The dynamic stochastic general equilibrium models used in BCBS (2010) also suggest that the use of a countercyclical buffer of plus-or-minus 2 percent reduces output volatility by around 15 percent.

40 This calculation assumes the consumer has constant relative risk aversion utility with a coefficient of relative risk aversion of five.

41 See the Federal Reserve Board working paper version of this analysis for an extensive comparison of the differences between our study's conclusions and that of similar work done by the BCBS (2010), Brooke et al. (2015), and the Minneapolis Fed (2016). It is available at https://www.federalreserve.gov/econres/feds/files/2017034pap.pdf.

$\underline{42}$ We focus on LCR compliance as we lack decent proxies for the NSFR in our Bankscope data.

$\underline{43}$ Depending on the specification, this coefficient is statistically significant at the 5 or 10 percent level with standard errors clustered at the country level. We treat this result with caution as we have not controlled for liquidity being an endogenous decision by banks. There is to our knowledge very little empirical work on the relationship between balance sheet liquidity and loss severity. Cifuentes, Ferrucci, and Shin (2005) use simulations and find that liquidity ratio requirements can limit "contagion" of bank failures because of illiquid asset fire sales. Malherbe (2014) finds in a theoretical model that liquidity ratio requirements can increase the probability of a financial crisis. 